\title{
Therapeutic Effects of Enrofloxacin in Mastitis-metritis-agalactia Syndrome: A Review
}

\author{
L. ŠČUKA ${ }^{2} Z$. ' M. ŠTUKELJ, VALENČAK ${ }^{1}$ \\ ${ }^{1}$ Veterinary Faculty, University of Ljubljana, Slovenia \\ ${ }^{2}$ Krka d.d., Novo Mesto, Slovenia \\ Received January 3, 2005 \\ Accepted September 5, 2006
}

\begin{abstract}
Ščuka L., M. Štukelj, Z. Valenčak: Therapeutic Effects of Enrofloxacin in Mastitismetritis-agalactia Syndrome: A Review. Acta Vet. Brno 2006, 75: 515-522.

The efficacy of enrofloxacin in the mastitis-metritis-agalactia (MMA)-syndrome was inspected by necessary clinical trials and by using a meta-analysis or systematic review. Numerous aetiologies or pathophysiologies can be involved in the MMA-syndrome. Fever, anorexia, vulva discharge and mastitis are the basic changes but the growth rate and survival of the litter are the main problem of MMA.

Our survey included 6 studies, of which four were entered in the meta-analysis itself; two studies dealt with the susceptibility profile of bacteria to enrofloxacin. As evident from the meta-analysis, enrofloxacin was effective in the treatment of the MMA-syndrome in pigs. Out of all studies, the results were statistically significant $(p<0.05)$ in three of them, whereas the overall result of metaanalysis indicates a high efficacy of enrofloxacin $(p=0.002)$ in treatment of the MMA syndrome. In total, there were not more than $0.3 \%$ of less susceptible and non-resistant strains out of all surveyed strains $E$. coli $(\mathrm{n}=295)$ within MMA-sydrome and the MIC value for $E$. coli ranged between 0.03 and $0.06 \mu \mathrm{g} / \mathrm{ml}$. The high efficacy of enrofloxacin in the MMA-syndrome therapy has been confirmed by meta-analysis and systematic review.
\end{abstract}

Pigs, dysgalactia, fluoroquinolones, meta-analysis

The characteristic of the mastitis-metritis-agalactia (MMA) syndrome is that during the first few post-parturition days the sow produces no or an insufficient quantity of milk, and is affected by fever and disturbances in its general condition. Mastitis is not always present and metritis only exceptionally. This is why the interpretation of the syndrome is inaccurate and may be misleading. Therefore the problem is described as postpartum dysgalactia syndrome (PPDS) (Klopfenstein et al. 1999).

Severe forms of MMA are rare. The major problem is loss in piglets. Economic loss results in a number of factors and therefore is difficult to estimate. The death rate of affected sows is low. The cost of extra care and treatment is hard to assess. The piglets suffer more than the affected sow. The mortality of piglets nursed by sows affected with MMA was $55.8 \%$, whereas that of piglets nursed by healthy sows was 17.2\% (Bäckström et al. 1984). Problem litters from apparently healthy sows are a common observation in modern farrowing units and are a major concern for the herd manager because these litters are responsible for most pre-weaning mortalities and poor growth rates. Moreover, poorly growing piglets lead to post-weaning problems (Klopfenstein et al. 1999).

The aetiology and pathogenesis of the disease have not as yet been completely elucidated. In the MMA syndrome we speak about a complex aetiology, which besides pathogenic microbes (the most common ones are E. coli, Klebsiella sp., Mycoplasma sp., Streptococcus sp. and Staphylococcus sp.) also includes hormonal disturbances, which, however, are probably not the primary cause. Factors contributing to the development of the syndrome include excessive feeding, imbalanced diet, mouldy feed (mycotoxins), contaminated and

Address for correspondence:

Marina Štukelj, University of Ljubljana, Veterinary faculty

Institute of the health care of pigs

Gerbičeva 60, 1000 Ljubljana

Slovenia
Phone: + 38614779206

Fax: + 38612832308

E-mail: marina.stukelj@vf.uni-lj.s

http://www.vfu.cz/acta-vet/actavet.htm 
overheated stables, late introduction into the farrowing pens, agitation and other stress factors. Many authors have suggested a relationship between bacteriuria and reproductive disorders with MMA. Sows developing MMA have much higher prevalence of urinary tract infections in the preceding gestation period than sows with a normal puerperium (Miquet et al. 1990).

Frequently the first symptom of MMA is fever exceeding $39.5^{\circ} \mathrm{C}$. During the first few hours following parturition the sow may lactate normally, but later the teats may contain only a few drops of or no milk at all. The sows suffer from apathy, they usually lie on the abdomen and are affected by inappetence and constipation. The bacteria causing mastitis are mainly coliforms. Coliform mastitis has a worldwide distribution. An average incidence is postpartum agalactia of $12.8 \%$, with a variation among individual herds from $0.5 \%$ to $50 \%$ (Hermanss on et al. 1987). Milk production is altered, and when many glands are affected, the growth of the piglets may be inadequate. Piglets from sows with mastitis have been reported to have lower weight, but the difference was not significant (Ross et al. 1975). In many studies on the importance of mastitis as a pathological entity it is not always clear whether the sows were selected for the presence of mastitis or because the litter had retarded growth and high mortality (Ross et al. 1975; Ross et al. 1981). Mortality of piglets may result from lengthened farrowing time, crushing by the sows, starvation and impaired immunity to infectious agents because of insufficient uptake of colostrum immunoglobulins (Bertschinger 1999).

The following measures should be taken for the MMA syndrome prophylaxis: the sows should be introduced in time (10 - 14 days prior to farrowing) into clean and disinfected farrowing houses where the temperature should not be too high for the sow. It is recommended that bedding material be available so that the sow can make a nest. A few days before farrowing feed rations should be reduced to a fifth, while on the day before farrowing and on the first postpartum day a complete feed restriction and water ad libitum is recommended. A good strategy to reduce the consequences of MMA should be based on three levels of intervention: (1) defining a treatment for the diseased postpartum sows, (2) rapidly identifying the problem litters of sows without clinical manifestations and determining a treatment for those sows and piglets, and (3) reducing the incidence of problem litters in the herd (Klopfenstein et al. 1999).

\section{Systematic review}

Table 1. Differences between Narrative Reviews and Systematic Reviews (Meta-analysis) (after Mulrow and Cook, 1998)

\begin{tabular}{|l|l|l|}
\hline Feature & Narrative Review & Systematic Review (Meta-analysis) \\
\hline Question & Often broad in scope & Often a focused question \\
\hline Sources and search & Usually not specified, potentially biased & $\begin{array}{l}\text { Comprehensive sources and explicit } \\
\text { search strategy }\end{array}$ \\
\hline Selection & Usually not specified, potentially biased & $\begin{array}{l}\text { Criterion-based selection, uniformly } \\
\text { applied }\end{array}$ \\
\hline Appraisal & Variable & Rigorous critical appraisal \\
\hline Synthesis & Often a qualitative summary & Quantitative summary \\
\hline Inferences & Sometimes evidence-based & Usually evidence-based \\
\hline
\end{tabular}

Systematic reviews are concise summaries of the best available evidence that addresses sharply defined questions, they seek to assemble and examine all the high quality evidence on a specific question at hand. These strategies include a comprehensive search of all potentially relevant articles and the use of explicit, reproducible criteria in the selection of 
articles for review. When the results of primary studies are summarized but not statistically combined, the review may be called a qualitative systematic review. A quantitative systematic review, or meta-analysis, is a systematic review that uses statistical methods to combine the results of two or more studies (Mulrow and Cook 1998).

Meta-analysis is the process of using statistical methods to review and combine the results of different, independent clinical studies and of particular importance in the assessment of therapeutic efficacy, since individual studies do not provide an overview of topic in its entirety.

\section{Enrofloxacin characteristics}

Enrofloxacin is a fluoroquinolone chemotherapeutic which was developed exclusively for use in veterinary medicine. In extremely low concentrations and rapidly after administration it acts bactericidally against most Gram-negative and Gram-positive bacteria, but it also has a mycoplasmocidal effect. Efficacy of fluoroquinolones is related to both, the maximum concentration and the time above the minimal inhbitory concentration (MIC) value. In vitro pharmacokinetic models have shown that maximum concentrations of active substance, 8 times in excess of MIC, have produced a $99 \%$ reduction of bacteria and a 24-hour inhibition of their growth. The intensity of exposure may be quantified as the ratio between the area under the time-concentration curve - AUC, and the minimal inhibitory concentration for the causative pathogens (MIC); a short term for this ratio is AIUC - area under the inhibitory plasma concentration curve. For example, if in enrofloxacin therapy the AIUC is higher than 125, the probability of clinical and microbiological cure is above $80 \%$, otherwise it only reaches $42 \%$, or $26 \%$ in microbiological cure. Resistance to fluoroquinolones is also reduced to a minimum if the above parameters are taken into consideration; $\mathrm{C}_{\max } / \mathrm{MIC}$ ratio is at least 8 - 10 and $\mathrm{AUC} / \mathrm{MIC}$ at least $100-125$ (Walker et al. 2000). This is valid for originator enrofloxacin products as well as for those which have proved to be bioequvalent.

The efficacy of enrofloxacin in MMA was inspected by necessary clinical trials and by using a meta-analysis or systematic review.

\section{Materials and Methods}

Six studies were included in the survey; out of these, four were included in the meta-analysis (efficacy):

Mendler et al. (1997), Rose et al. (1996), Shoening and Plonait (1990) (2 studies: one in comparison with furazolidon and sulfadimidine in a commercial premix and second in comparison with trimethoprim + sulfadimidin); two studies dealt with the susceptibility profile of bacteria to enrofloxacin. Studies of Toriumi et al. (1998), and Na omi and Bertschinger (1990) were excluded from the analysis because of inadequacy of data.

All studies which examined susceptibility were comparative (eg. comparison between different antimicrobials). In all studies there were a total of 295 strains of $E$. coli examined for susceptibility to enrofloxacin. $\beta$-haemolytical streptococci which were presented in milk in high percentage and cervical swabs, were also examined for susceptibility.

Among four clinical studies one study dealt with economic parameters in pig rearing when using enrofloxacin.

The meta-analysis included 1,423 sows, of these 712 sows were allocated to test groups receiving enrofloxacin and 711 to control groups or receiving comparator treatment (see Table 2).

Meta-analysis is the process of using statistical methods to review and combine the results of different, independent clinical studies. Meta-analysis is of particular importance in the assessment of therapeutic efficacy, since individual studies do not provide an overview of a topic in its entirety. As their samples are usually small, individual studies cannot provide a quantitative evaluation of the effect of treatment, nor can they test the null hypothesis. Prior to meta-analysis, the traditional method was a narrative discourse on previous findings, which, however, could be misleading and subjective.

Systematic reviews are exact summaries of the best evidence related to exactly specified clinical dilemmas.

There are many definitions of the term meta-analysis. The most frequently used definition is the one by Huque (1998): Meta-analysis refers to a statistical analysis that combines or integrates the results of several independent clinical trials considered by the analyst to be combinable.

Besides quantitative integration, meta-analysis offers a vast improvement in discovering and studying the differences in the available scientific material and in achieving or at least offering, the most plausible explanations and even discovering new recognitions.

A brief summary of all meta-analysis procedures would comprise the following rational definitions: 
Table 2. Short survey of studies included in meta-analysis and systematic review

\begin{tabular}{|c|c|}
\hline \multirow{2}{*}{$\begin{array}{l}\text { Author, year of the publication, } \\
\text { number of animals included, (reference) }\end{array}$} & Meta-analysis and systematic review parameters \\
\hline & Comparative control group \\
\hline \multirow[t]{2}{*}{$\begin{array}{l}\text { 1. Mendler et al. } 1997 ; \mathrm{n}=90 \text { (sows) } \\
\mathrm{n}=740 \text { (piglets) }\end{array}$} & $\begin{array}{l}\text { - clinical efficacy (preventive and treatment) } \\
\text { - mortality } \\
\text { - economic parameters (number of born piglets) }\end{array}$ \\
\hline & - negative control (if necessary treatment of sows with oxytocin) \\
\hline 2. Awald-Masalmeh et al. 1990; & $\begin{array}{l}\text { - in vitro susceptibility testing of } E \text {. coli (\% susceptibility } \\
\text { in millk, cervical swabs and feces) }\end{array}$ \\
\hline \multirow[t]{2}{*}{ 3. Rose et al.1996, $\mathrm{n}=350$ (sows) } & - clinical efficacy, mortality \\
\hline & - cefquinome $(2 \mathrm{mg} / \mathrm{kg}$ body $)$ \\
\hline \multirow[t]{2}{*}{$\begin{array}{l}\text { 4. Schöning and Plonait } 1990 \text {, } \\
\qquad \begin{array}{l}n=828 \text { (sows in first trial) } \\
n=185 \text { (sows in second trial) }\end{array}\end{array}$} & $\begin{array}{l}\text { - clinical efficacy (metaphylaxis, treatment) } \\
\text { - in vitro susceptibility testing of } E \text {. coli and } \beta \text {-haemolytic } \\
\text { streptococci (\% susceptibility) } \\
\text { - feeding disorders } \\
\text { - pharmacokinetics of enrofloxacin in milk }\end{array}$ \\
\hline & $\begin{array}{l}\text { - furazolidon and sulfadimidine in a commercial premix } \\
\text { - negative control (commercial premix) } \\
\text { - trimethoprim + sulfadimidin }\end{array}$ \\
\hline 5. Toriumi et al. $1998, \mathrm{n}=27$ (sows) & $\begin{array}{l}\text { - clinical efficacy } \\
\text { - incidence of individual pathogens in MMA sydrome }\end{array}$ \\
\hline \multirow[t]{2}{*}{$\begin{array}{l}\text { 6. Naomi and Bertschinger } 1990 \text {, } \\
n=24 \text { (sows) }\end{array}$} & $\begin{array}{l}\text { - clinical efficacy } \\
\text { - reisolation of causative bacteria }\end{array}$ \\
\hline & - negative control (commercial premix) \\
\hline
\end{tabular}

1. Definition of the problem and criteria for the inclusion of studies.

2. Positioning of studies, classification and coding of characteristics of individual studies and quantitative measurement of the studies' characteristics (scale).

3. Integration of results and comparison with the studies' characteristics (analysis and explication of results), and

4. Reporting of results (Sacks et al. 1987).

The Comprehensive Meta-Analysis (B oren ste in 2000) computer programme was used for statistical analysis.

Heterogeneity checking is performed by a funnel plot, which should be tested for asymmetry. It is a simple graphic presentation of data dispersal. Effect sizes are inserted on axis $\mathrm{x}$, while the standard deviation (error) is inserted on axis y. If heterogeneity is non-significant, the inserted data form a funnel with a big opening (funnel orifice) and a funnel end reaching on the top the total effect size value.

This method presents good agreement between the calculation of heterogeneity and graphic presentation.

\section{Results}

Fig.1. Meta-analysis of the efficacy of enrofloxacin treatment

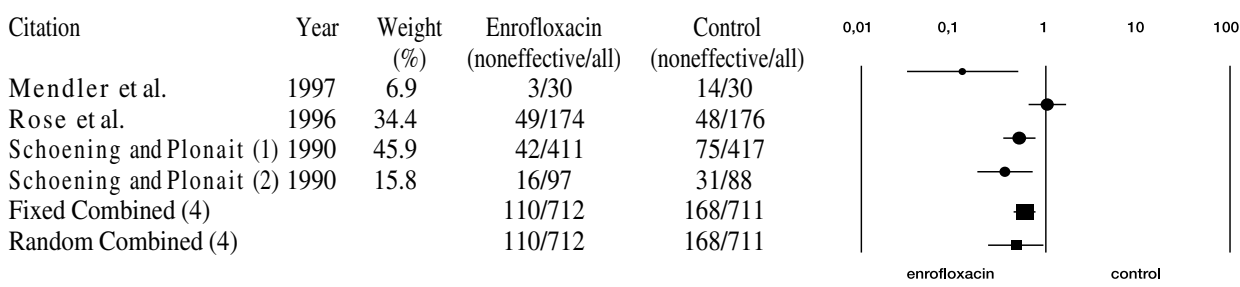

Homogeneity testing: $\mathrm{Q}=12.68$, d.f. $=3, \mathrm{P}=0.0054$

Q.....heterogeneity value $\left(\chi^{2}\right.$ distribution $)$; d.f.....degrees of freedom ; P.... probability

It is evident from the results in the graph that enrofloxacin treatment is more effective than comparative treatment of MMA syndrome $(p=0.002)$. 
The results of meta-analyses are presented graphically. The figures show compiled data on authors of individual studies, the year of study publication or performance, a numerical comparison between the treated and control group and the mean values of effect size with $95 \%$ confidence intervals. The odds ratio (OR) was used as a scale of magnitude for the effect size. The characteristic of OR is that a value of 1.0 means that a certain therapy has no effect; values below 1.0 indicate that the tested therapy (in our case the use of enrofloxacin) is better than that of the control or the comparator therapy group. Values above 1.0 indicate the advantage of the control or comparator therapy over the tested therapy. When in a graph the study presentation with its mean value and the two lines for the confidence interval does not intersect the value of 1.0, we speak about statistical significance at different levels, e.g. in 95 percent confidence intervals the $p$ level of statistical significance equals 0.05 ; in 99 percent intervals it equals 0.01 , etc.

In cases, however, where mean values with confidence intervals intersect the 1.0 value line, we cannot speak about statistical significance.

Values for homogeneity or heterogeneity (Q) were calculated for the graphs. We must always form a null hypothesis that all studies pertain to the same population. The $Q$ value is distributed as Chi-square probability distribution with $\mathrm{k}$ - 1 degrees of freedom (df), where $\mathrm{k}$ represents the number of processed studies. However, statistically non-significant $p$ values should not always be considered to be an independent and self-sufficient proof of homogeneity. Additional checking of dispersion of studies in the graph is obligatory. Also, when we have obtained evidence, or calculation of heterogeneity, we have to check the graph for the meaning of this dispersion: do the majority of studies indicate usefulness of treatment while some of them indicate the opposite; does usefulness of treatment itself vary greatly; or there may be some studies with outstanding deviations. If heterogeneity of $p<0.05$ had been calculated, the total effect was always additionally calculated using the random effects method.

The total effect size is always conditioned by weights of individual studies; therefore, in a meta-analysis we speak about a weighted total value of the effect size which, the same as for individual studies, is presented by mean value and confidence intervals. In the graph the weights for individual studies are shown as bigger or smaller full circles $(\bullet)$. This means that studies with smaller weights have smaller circles and those with larger weights have larger circles. The total effect size is shown as a full square ( $\bullet$ ).

Besides the graphic presentation of the meta-analysis results, funnel graphs (see Fig. 2.) were used to show a certain compilation of studies included in the meta-analysis. At first, funnel graphs were used in monitoring publication bias but now we know that they also indicate heterogeneity of studies and the quality of study methodology.

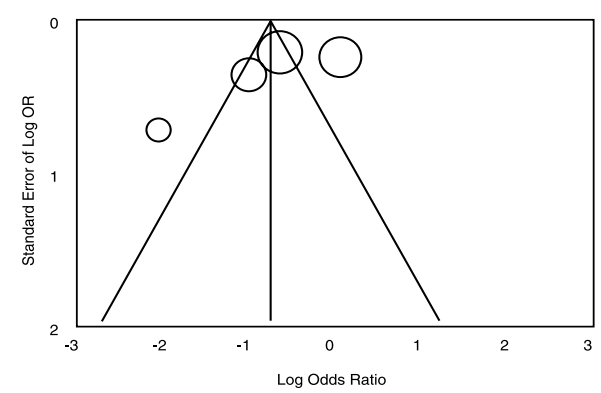

Fig. 2. Funnel plot standard error by effect size. From funnel plot it is evident that the studies included in Meta-analysis were heterogenous ( $p=0.0054)$. 
We also reviewed in vitro susceptibility of individual microbes to enrofloxacin and evaluated the MIC values.

Table 3. Number and percentage of susceptibile, less susceptible and resistant E. coli $(\mathrm{n}=295)$ to various antibacterials

\begin{tabular}{|l|r|r|r|}
\hline $\begin{array}{l}\text { Antibacterial } \\
\text { tetracycline }\end{array}$ & $\begin{array}{c}\text { Susceptibile } \\
37(12.5 \%)\end{array}$ & $\begin{array}{c}\text { Less susceptibile } \\
2(0.7 \%)\end{array}$ & $256(86.8 \%)$ \\
\hline streptomycin & $55(18.6 \%)$ & $1(0.3 \%)$ & $239(81.1 \%)$ \\
\hline chloramphenicol & $142(48.1 \%)$ & $7(2.4 \%)$ & $146(49.5 \%)$ \\
\hline ampicillin & $160(54.2 \%)$ & $3(1.0 \%)$ & $132(44.8 \%)$ \\
\hline neomicin & $182(61.7 \%)$ & $4(1.4 \%)$ & $109(36.9 \%)$ \\
\hline gentamicin & $292(99.0 \%)$ & $2(0.7 \%)$ & $1(0.3 \%)$ \\
\hline enrofloxacin & $294(99.7 \%)$ & $1(0.3 \%)$ & $0(0.0 \%)$ \\
\hline sulfametoxasol+trimethoprim & $94(31.9 \%)$ & $2(0.7 \%)$ & $199(67.4 \%)$ \\
\hline
\end{tabular}

There were no resistant strains to enrofloxacin, only one was less susceptibile. It is evident from the results that enrofloxacin and gentamicin are the most effective antibacterials in vitro. MIC value for enrofloxacin ranged between 0.03 and $0.06 \mu \mathrm{g} / \mathrm{ml}$.

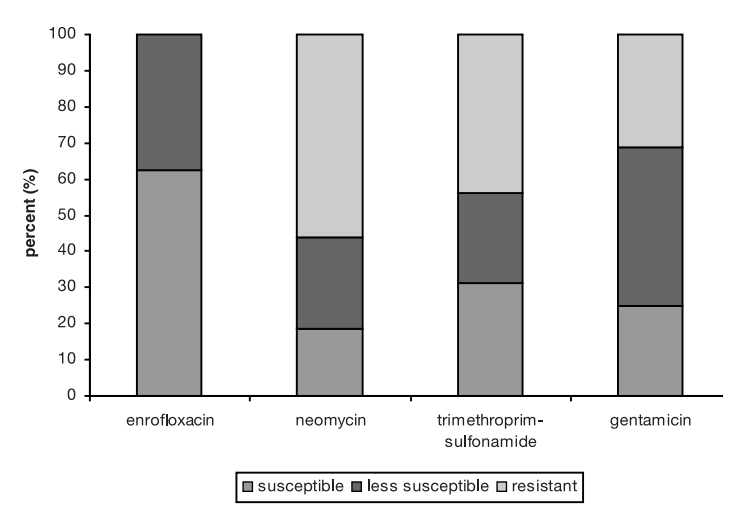

Fig. 3. Susceptibility of $\beta$-haemolitycal streptococci to various antibacterials (modificated after Shoening; $\mathrm{n}=16$ )

It is evident from Graph 3 that there were no enrofloxacin resistant strains of $\beta$-haemolytical streptococci. Less susceptibile strains appeared in less than $40 \%$.

In vitro susceptiblity testing showed excellent susceptibility of main causative agents (e.g. E. coli, a-haemolytical streptococci) of the MMA-syndrome to enrofloxacin shown in Table 3 and Fig. 3. The samples were taken from milk, cervical swabs and faeces of sows.

\section{Discussion}

Our survey included 6 studies, of which four were entered in the meta-analysis itself while others dealt with the susceptibility profile of bacteria to enrofloxacin. The studies included in the meta-analysis covered the period between 1990 and 1998 and gave the following results:

In the analysis of efficacy we established a heterogeneity of included studies, therefore the total effect size was calculated using a random model $(p=0.04)$, which is also evident from the distribution of studies in the funnel graph. We attributed this heterogeneity primarily to the study by Mendler et al. (1997) which slightly stands out from other studies. 
Nevertheless, a sensitivity analysis not including this study also demonstrated heterogeneity $(p=0.02)$. We have consequently concluded that the reason for it lies in the design, performance and different size of the studies.

As evident from the meta-analysis, enrofloxacin was effective in the treatment of the MMA-syndrome in pigs. Except for study of Rose et al. (1996) (which has rather neutral results), all other studies spoke in favour of treatment with enrofloxacin. Out of all studies, the results were statistically significant $(p<0.05)$ in three of them, whereas the overall result indicates a high efficacy of enrofloxacin $(p=0.002)$ in treatment of the MMA-syndrome.

Survey of susceptibility

In total, there were not more than $0.3 \%$ of less susceptible and no resistant strains out of all surveyed strains E. coli $(\mathrm{n}=295)$ within the MMA-sydrome and the MIC value for E. coli ranged between 0.03 and $0.06 \mu \mathrm{g} / \mathrm{ml}$.

Moreover, the use of enrofloxacin reduces problems with nutrition and sick animals recover faster than those in the control group or those receiving comparative treatment. The sows that received treatment at an early stage of disease ensured sufficient milk production and its intake by the piglets. Metaphylaxis showed to be also useful in preventing the cases of MMA and thus reducing their number (Schöning and Plonait 1990).

Various bacteria are often isolated from milk and cervical swabs of diseased animals. For the sake of such mixed infections, broad spectrum antimicrobials are required for the treatment.

Resistance of $E$. coli strains to enrofloxacin also remains low, especially if enrofloxacin is used judiciously.

Our results have confirmed high efficacy of the use of enrofloxacin in the MMAsyndrome, and that the use of enrofloxacin is economically justifiable and is thus the right drug of choice in treating this disease in pigs.

\section{Léčebné účinky enrofloxacinu u syndromu mastitidy-metritidy-agalakcie: systematický přehled}

Účinnost enrofloxacinu u syndromu mastitidy-metritidy-agalakcie byla zkoumána pomocí nezbytných klinických zkoušek a použitím meta-analýzy neboli systematického přehledu.

Syndrom MMA může zahrnovat četné etiologické nebo patofyziologické změny. Mezi základní změny patři horečka, nechutenství, poševní výtok a mastitida, avšak hlavní problém MMA spočívá v míře růstu a přežití vrhu selat.

Do průzkumu jsme zahrnuli 6 studií, z nichž byly čtyři zadány do samotné meta-analýzy; dvě studie se zabývaly citlivostí bakterií na enrofloxacin. Jak je patrné z meta-analýzy, enrofloxacin byl účinný př́i léčbě syndromu MMA u prasat. Výsledky byly signifikantní $(p<0.05)$ u tří z celkového počtu studií, přičemž celkový výsledek meta-analýzy poukazuje na vysokou účinnost enrofloxacinu $(p=0.002)$ při léčbě syndromu MMA. Ze všech zkoumaných kmenů $E$. coli $(n=295)$ v rámci syndromu MMA nebylo celkem více než $0,3 \%$ méně citlivých a žádné resistentní. Hodnota minimální inhibiční koncentrace (MIC) u E. coli byla v rozmezí 0,03 a $0,06 \mu \mathrm{g} / \mathrm{ml}$. Vysokou účinnost enrofloxacinu při léčbě syndromu MMA potvrdila meta-analýza a systemický přehled.

\section{References}

ANON 1998: Postpartum dysgalactia syndrome and mastitis in sows. In: AIELLO SE(Ed.): The Merck Veterinary Manual, $8^{\text {th }}$ ed, Philadelphia, pp. 1020.

AWAD-MASALMEH M, BAUMGARTNER M, PASSERING A, SILBER R, HINTERDORFER F 1990: Bakteriologische Untersuchungen bei an puerperaler Mastitis (MMA-Syndrome) erkrankten Sauen verschidener Tierbestände Österreichs. Tierärztl Umsch 45: 526- 535

BÄCKSTRÖM L, MORKOC AC, CONNOR J, LARSON R, PRICE W 1984: Clinical study of mastitis-metritisagalactia in sows in Illinois. J Amer Vet Med Assoc 185: 70-73 
BERTSCHINGER HU 1999: Coliform mastitis. In: STRAW BE (Ed.), Diseases of swine, 8 th edition, Blackwell Science, Ames, pp. 457-464

BORENSTEIN M. Comprehensive meta-analysis: manual for meta-analysis. Eaglewood: Biostat, 2000 (computer programme)

HERMANSSON I, EINARSSON S, LARSSON K, BÄCKSTRÖM L 1978: On the agalactia postpartum in the sows: a clinical study. Nord Vet Med 30: 465-473

HUQUE MF. Experiences with meta-analysis in NDA submissions, Rockville 1998. In: Proceedings of the Biopharmac. section of the Am Stat Assoc 2: 28-33

KLOPFENSTEIN C, FARMER C, MARTINEAU GP 1999: Diseases of the mammary glands and lactation problems. In: STRAW BE (Ed.), Diseases of swine, $8^{\text {th }}$ edition, Blackwell Science, Ames, pp. 833-860

MULROW C, COOK DC 1998: Systematic reviews. Synthesis of best evidence for health care decisions. Philadelphia: American College of Physicians: pp. 5-12

MENDLER Z, SUDARIC B, FAZEKÁS J, KNAPIC A, BIDIN S 1997: Vetoflok 5\% otopina za injekcije u preventivi i terapiji sindroma MMA u krmača. Prax Vet 45(3): 261-265

MIQUET JM, MADEC F, PABOEUF F 1990: Epidemiology of farrowing disorders in the sow: preliminary results of a prospective inquiry in 2 farms. In: Proceedings of the $11^{\text {th }}$ International Pig Veterinary Society Congress, Lausanne, IPVS, pp. 472

NAOMI O, BERTSCHINGER HU 1990: Prophylaxis of experimentally induced coliform mastitis in the sow with enrofloxacin (Baytril). In: Proceedings of the $11^{\text {th }}$ International Pig Veterinary Society Congress, Lausanne, IPVS, pp. 186

ROSE M, SCHNURRBUSCH U, HEINRITZI K 1996: The use of cefquinomein the treatment of pig respiratory disease and MMA syndrome. In: Proceedings $14^{\text {th }}$ International Pig Veterinary Society Congress, Bologna, IPVS, p. 317

ROSS RF, ORNING AP, WOODS RD, ZIMMERMANN BJ, COX DF, HARRIS BDJ 1981: Bacteriologic study of sows agalactia. Amer J Vet Res 42: 949-955

ROSS RF, ZIMMERMANN BJ, WAGNER WC, COX DF 1975: A field study of coliform mastitis in sows. J Amer Vet Med Assoc 167: 231- 235

SACKS HS, BERRIER J, REITMAN D, ANCONA-BERK VA, CHALMERS TC 1987: Meta-analyses of randomized controlled trials. New Engl J Med 316: 450-455

SCHÖNING G, PLONAIT H 1990: Metaphylaxe und Therapie des MMA- Syndromes der Sauen mit Baytril. Dtsch Tierarztl Wochenschr 97 (1): 5-10

TORIUMI H, FUJITA S, NAKAMURA A 1998: Enrofloxacin against MMA- syndrome of Sows. In: Proceedings of the $15^{\text {th }}$ International Pig Veterinary Society Congress, Birmingham, IPVS, p. 182

WALKER RD 2000: Flouroqinolones. In: PRESCOTT JF (Ed.): Antimicrobial therapy in veterinary medicine, $3^{\text {rd }}$ edition, Ames: Iowa State University Press, pp. 315-339 